Article

\title{
The Architecture of the Metacity: Land Use Change, Patch Dynamics and Urban Form in Chiang Mai, Thailand
}

\author{
Brian McGrath ${ }^{1, *}$, Somporn Sangawongse ${ }^{2}$, Danai Thaikatoo ${ }^{3}$ and Martina Barcelloni Corte ${ }^{4}$ \\ ${ }^{1}$ Parsons School of Design, The New School, New York, NY 10011, USA; E-Mail: mcgrath@newschool.edu \\ 2 Department of Geography, Chiang Mai University, 50200 Chiang Mai, Thailand; E-Mail: somporn@chiangmai.ac.th \\ ${ }^{3}$ Faculty of Architecture, Chulalongkorn University, 254 Pathumwan Bangkok, Thailand; E-Mail: danathai@gmail.com \\ ${ }^{4}$ Laboratory of Urbanism, École Polytechnique Fédérale de Lausanne, 1015 Lausanne, Switzerland; \\ E-Mail: martina.barcellonicorte@epfl.ch \\ * Corresponding author
}

Submitted: 24 January 2017 | Accepted: 16 March 2017 | Published: 29 March 2017

\begin{abstract}
This essay analyzes the spatial and temporal dynamics which have emerged from the rapid development of Chiang Mai, Thailand over the last four decades. Modern urbanization since the 1980s in the previously remote Chiang Mai-Lamphun Valley has coincided with digital and financial globalization, neo-liberal governance, and the articulation of a new geological era of the Anthropocene based on evidence of human induced climate change. This time frame serves as a lens to theorize the architecture of the "metacity", a new urban form and new form of urban practice responding to the demands of global digital financial networks and neo-liberal trade policies, but grounded in the ecology and life worlds of particular localities. The metacity appears in Chiang Mai within the interstices of a particularly fragmented rural/urban mix within a self-organized rather than plan-controlled built environment. The entire valley has been the site of intensive inhabitation for centuries, and recently urbanized, yet is spatially heterogeneous, extensive and patchy rather than ordered, bounded and uniform. The resulting landscape is marked by a disjunction between a feudal wet-rice cultivation land tenure structure overlaid with a market-based typology of urban real estate products with little enforcement of land use controls. The essay begins with theorizing the form of the metacity, continues with a description of the Chiang Mai case study, and concludes with a general assessment of the need to create a new form of metacity urban practice. A metacity design practice would re-conceptualize urban theories and forms by inking architectural and ecological thinking with inclusive social practices, enhanced by new digitally-enhanced urban imaginaries and new representational tools of mapping, modeling and design.
\end{abstract}

\section{Keywords}

Chiang Mai; Desakota; land use change; landscape ecology; metacity; Thailand; urban design; urban/rural mix

\section{Issue}

This article is part of the issue "Urban Forms and Future Cities", edited by Luca D'Acci (Erasmus University Rotterdam, The Netherlands), Tigran Haas (KTH Royal Institute of Technology, Sweden) and Ronita Bardhan (Indian Institute of Technology Bombay, India)

(C) 2017 by the authors; licensee Cogitatio (Lisbon, Portugal). This article is licensed under a Creative Commons Attribution 4.0 International License (CC BY).

\section{Introduction: Metacity Theory}

Over the last four decades, the digitalization of global finance and the deregulation of world trade preceded the recent exponential development of a dense and volatile cloud of social media, communication and information.
While $19^{\text {th }}$ century industrialization produced the spatial logic of the modern metropolis and American postwar hegemony produced the late $20^{\text {th }}$ century oil-based megalopolis, the digitally networked $21^{\text {st }}$ century will produce a new form of meta-urbanism. Metacity theory follows the distribution logic of metacommunity and 
metapopulation theories in ecology (Pickett, 2015), and is difficult to disentangle from pre-digital urban forms and inherited urban images. The metacity is both virtual and actual, concentrated in the hyper centers of global capital, but also widely distributed in new hybrid mixtures in the urbanizing countryside. While information and prosperity has been broadly dispersed through this new decentralization, it has also resulted in the hyperconcentration of inside knowledge and wealth among the "1\%" (Picketty, 2014). The metacity appears within the shells of the fragmented $20^{\text {th }}$ century metropolis, as well as in new $21^{\text {st }}$ century conurbations sprawling across formerly rural and wild territories. This essay employs the theoretical framework of the metacity, a term recently introduced in urban design and ecology discourse (McGrath \& Pickett, 2011; McGrath \& Shane, 2012), in order to develop methods to decipher the architectural form, social equity as well as ecological performance of Chiang Mai, Thailand. The metacity framework serves as a basis for a call for an urban practive of ecologically and socially activist design, linking a new digitally enhanced urban imaginary with the actual reality of contemporary urban life.

\subsection{Contradictory Urban Theories}

The urban century has arrived at the very moment that the definitions and meanings of the terms city, metropolis and territory have been exhausted. The architecture of the city (Rossi, 1982) and collage city (Rowe \& Koetter, 1978) recognized the slow evolution of the traditional European city as a singular artifact with localized typological and morphological structures. Furthermore, they imagined a new role for architects, not merely the as designers of buildings in the city, but as specialists in the form of the city. The European metropolis evolved to a collision of fragments between the traditional city accommodated the new scales and technologies masked in grand architectural imagery (Shane 2008). More recently, the figure of the metropolitan architect was revived as a retroactive manifesto, exploiting the technologies of the industrial age to empower the architect to artificially simulate nature as urbanism is subsumed within the big architecture of New York's skyscrapers, theme parks such as Coney Island and corporate complexes such as Rockefeller Center (Koolhaas, 1978).

The structure of the American road based city has also been theorized, starting with Venturi, Scott Brown and Isenour's Learning from Las Vegas (1967) and Banham's four ecologies of Los Angeles (1972), continued with the work of Gandalsonas (1999) and Pope (1996). In the post-war car-based city, the architect was relegated to the corporate campus, museum or elite residence, while landscape and advertisement branders were the design firms more in tune with this new urban form. Banham uses the word ecology metaphorically to designate the various geographies and social groupings of the sprawling American city. Ecology is also often used as a metaphor in urban sociology, where the megacity and slum theory became a new focus in urban studies (Rao, 2006). Here architects are often seen as in the way of the desires of residents. Chance, informality and event is celebrated in Tschumi's analysis of Manhattan (1983) and Atelier Bow Wow's Tokyo (Tukamoto, Kuroda, \& Kaizima, 2001), updating the architect's role as cultural interpreter of the city.

All these authors describe radically different yet singular theories of urbanism, much like the story of the blind men and the elephant. They all describe only one idea of urbanism, one kind of city, and one prescribed method and role for the architect. Metacity theory does not place itself in opposition to this sample of urban theories, but instead is introduced as a theory of theories (McGrath, 2012). Metacity theory promotes a radically inclusive assemblage of ideas about the traditional city, the fragmented metropolis, the sprawling megalopolis and the imploding megacity through new communication, information and automation technologies and a new role for the architect/urban designer as the mediator, translator and negotiator between various urban actors. The metacity practitioner confronts disruptive urban change emerging directly from the demands of financial volatility, social uncertainty and unevenness, spatial disjunctions and cultural fragmentation played out in lived landscapes.

The historical city evolved through a slow process of aggregation, adaptation; the metropolis employed architecture as a cultural façade for a massive civil engineering project; and the megalopolis prioritized highway construction to seed a self-organizing logic of speculative development equipped with graphic designed wayfinding within a green veil of landscape design (McGrath \& Shane, 2012). The metacity instead inverts the uniformity of the traditional city, the power logic of the modern metropolis and the social isolation of the megalopolis recognizing that urban creativity, invention and change is best when self-determined and socially produced.

Metacity theory was born from an exhaustion of singular urban models of urban form, recognizing the rise of activism in civil rights and environmentalism, and the emergence of new sensing, communication and imaging technologies. "Meta" implies that which exists above and beyond the traditionally defined city and territory, but also above and beyond current professional practice. If the metropolis was the result of a colonial world system, the megalopolis and megacity were created in the Cold War order following its collapse. The metacity emerges in the multipolar world of late global capital aided by new information and communication technology, which allow for new forms of both concentration and dispersal across a planet that has reached is capacity to accommodate human activities. Meta urbanization is unbounded, at once urban and rural, center and periphery. Contemporary theories of disturbance ecology give us an understanding of the environment neither in balance nor equilibrium, but in a constant state of flux. The 
ecology of the metacity should be understood within a complex adaptive system in disequilibrium, and the social actors of the city are seen as integral actors shaping nature (Pickett, 2015).

An archaeology of the metacity follows a trajectory of the shifts in urban design practice in relation to new forms of subjectivity, representation and social activism (McGrath \& Pickett, 2015). In New York City and London in the 1980s, the metacity first appeared through 'damage control' by local activist designers, often blind to larger logic and global impact that the introduction of electronic trading on Wall Street and the City, and the Thatcher/Reagan policies of deregulation of markets and trade. In August 1991, the worldwide web was launched, opening up the use of the internet beyond military, government and academic users. The introduction by NTT DoCoMo in Tokyo of the first smart phones to achieve mass adoption in a country, in 1999, Ima Hima (are you free now?) enabled customers to locate themselves and others within the vast chaos of the megacity, and to text simultaneously with a group of friends. Civil engineering and metropolitan architects produced the form of Haussmann's Paris, but the social space of contemporary Tokyo produced text messaging.

\subsection{The $21^{\text {st }}$ Century}

The $21^{\text {st }}$ century began with an attack on New York's World Trade Center, physical symbols of global financial speculation and trade. Globalization became thought of as a threat as well as an opportunity, resulting in the widespread deployment of a web enhanced security and surveillance network. Facebook was founded in 2004 and the iPhone was introduced in 2007, just before the enormous shock of the worse financial crisis in the U.S.A. since the Great Depression. This current decade began with Occupy Wall Street, one of many protests organized via widely dispersed on-line social activism. This decade is ending in a period of revanchist political retreat from the open progressive promise of digital and financial globalization. The project of the metacity seeks to uncover the urban spatial practice under capitalism in Picketty's $21^{\text {st }}$ century. Flash mobs, occupation protests, scandal, fake news, and self-promotion are spatial practices both actual and virtual, and call for architects and designers to take a political position.

Three end-of-the- $20^{\text {th }}$ century prophets of the metacity are Henri Lefebvre (1991) Terrance McGee (1996) and Paul Krugman (1996). Lefebvre's triad of social practice, representations of space and representational space is increasingly converging in the metacity where the mobile phone, GPS, satellites, the Internet and the cloud intertwine. Hand held digital communication and information technology stored and distributed through the cloud has made more a volatile landscape of occupations, adaptations and appropriations. The possibilities of new forms of computer generated representations of space have proliferated and come to domi- nate the architecture profession since the 1990s have often not been met by actual new forms of representational space. Hyperreal renderings are commonplace, but new ways of seeing are more elusive (McGrath, 2008). In Lefebvre's terms, mediated representation has made more volatile the disjunction between social practice, the spaces of representation and the representation of space.

Evidence has been recently revealed about the unevenness of recent urbanization, yet hundreds of millions in Asia have left poor subsistence peasant livelihoods and have entered middle class through the globalized urban economy in the last four decades (Figure 1). If the two-stroke motorcycle was the key technology in what McGee has called the rural/urban mix of Desakota, mobile communication and information technology has produced a much more heterogeneous, volatile diffuse rural/urban mix, not as a transitional state of an expanding metacity, but as a new urban form. The motorcycle and the cell phone are powerful tools that give access to job markets and economies ending the isolation of rural villages, now often juxtaposed next to new peri-urban real estate developments. Arguably, much of the urbanization of the $21^{\text {st }}$ century has already proliferated and will continue to spread within the wet rice cultivation areas of South, East and Southeast Asia.

The neoliberal city itself was recognized as self-organizing in space and time at various hierarchically nested scales. Self-organized, atomistic interactions among individual agents can spontaneously generate largescale order. Small differences in initial conditions can have large effects on long-run outcomes through discontinuous change where small quantitative changes in the underlying factors that drive location will sometimes produce large, qualitative changes in behavior (Krugman, 1996). Morphological fragments based on a marketbased typology of urban real estate products constitutes the production of the speculative city, sprawling along with the universal recipe of development: road and highway construction.

The technological shifts that have produced our new urbanized global society have just begun to unfold. The next decades will see further applications of artificial intelligence, autonomous vehicles, giant data cloud farms, and ubiquitous drones and robotics replacing millions of jobs. A metacity practice would begin with the integration of Lefebvre' production of space, McGee's Desakota and Krugman's self-organization in space. New media and communications systems, both close-up and remote, provide tools for the architecture of the metacity to be engaged by a wider range of actors than the current client based system of the metropolitan architect or the corporate landscape of the megalopolis. Representation takes on a new role of persuasion by altering cognitive images of the city, rather than in articulating specialized units of construction (McGrath \& Shane, 2007). Digital representations have brought analytical tools to any smart phone as well as provided a bridge for 


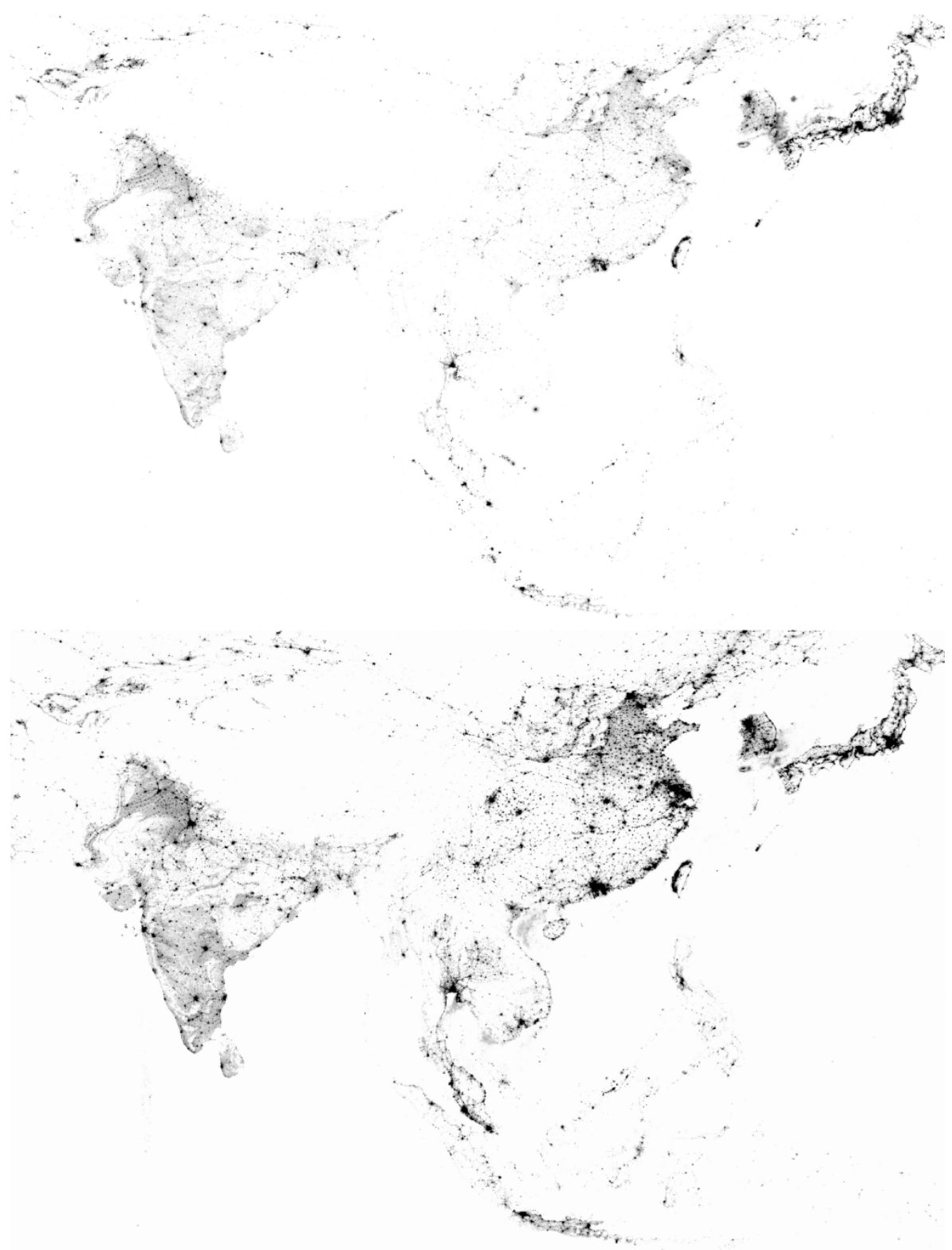

Figure 1. Comparison of nighttime satellite imagery, 1992-2013 indicates the extent of urbanization in South, Southeast and East Asia over two decades. Data courtesy: Marc Imhoff of NASA GSFC and Christopher Elvidge of NOAA NGDC.

transdisciplinary research between architecture, social science and ecology. Drones and sensors provide farmers smart technologies to monitor irrigation, crop growth and pests.

\subsection{The Ecology of the Metacity}

The very metabolism of urbanization needs to be fundamentally transformed to insure to the survival of life on this planet and equitable access to its limited resources. The distribution logic of metacommunity and metapolulation theories in ecology provide a way forward for a metacity design project and practice (Pickett, Cadenasso, \& McGrath, 2013). Pickett has called the metacity a spatially extensive, system of cities, suburbs and exurbs, structured as dynamic mosaics of patches, in which flows, distant connections, historical contingencies, and the dis- turbances act in spatially explicit ways (2012). The metacity is a patch dynamic system where differentiation is produced at various spatial and time scales. "Meta" in ecology refers to a system of systems, nested and dynamic, and the metacity requires a multi-scalar understanding. Local internal dynamics leads to larger system flux as flows between patches vary across boundaries and scales. The metacity approach is inclusive of the designed as well as the vacant and abandoned including conserved or derelict agriculture and wilderness. It disrupts the myth of escape from responsibility for the consequences of metabolic decisions such as off-site periphery from which to gather natural resources and dispose of waste (Pickett, 2012, p. 480).

For Pickett, a nested mosaic understanding begins with a recognition of urban patches as bounded volumes or spaces whose characteristics differ from adjacent ar- 
eas. Mosaics can be understood as simultaneously parts of larger patches and are made up of smaller patches. Patch mosaics are preeminently about spatial heterogeneity, adaptation, change and connection. Dynamism results from the flows of materials, energy, organisms, and information, but is also socially driven. The physical history of any city reflects adaptive social ecological process over time and an understanding of history is crucial to understanding the architecture of the metacity. A dynamic patch approach promotes adaptation resulting from both feedbacks and from larger contextual factors, such as climate, human and biotic migrations, and shifting economic investments can promote inclusion by design. Adaptation is multiscalar, consisting of nested mosaics that extend from households to regions. Patches are key to understanding social and ecological heterogeneity, but places these patches, at whatever scale, in some larger, spatial mosaic context. Patch mosaics invoke an ethos of inclusivity, recognizing the joint natural and cultural features of urban systems within spatially extensive dynamic systems in which flows, distant connections, historical contingencies and the disturbances of innovation and crisis act in spatially explicit ways (Pickett, 2012).

The Urban Design Working Group as part of the Baltimore Ecosystem Study has experimented with an interdisciplinary metacity design practice by creating design scenarios for neighborhoods across a regional watershed (McGrath \& Pickett, 2011). Solutions to regional ecological problems are based on the degree of cooperation or independence neighbors seek. Some scenarios provide ideas for individuals to alter their own property, while others demand taxes or bonds to transform public right of ways. Most interesting are solutions that provide neighbor to neighbor cooperation-around shared backyards, adjacent driveways, or common water, agricultural or forest resources. Private, public or shared solutions can be enacted differently across political jurisdictions in order to address larger issues such as exporting nitrogen downstream, but also flood or drought risk scenarios. The metacity design approach links neighborhood choices with bio-regional issues.

The next section of this paper elaborates on the architecture of the metacity through a multi-scalar spatial and temporal analysis of one in-depth case study. Chiang Mai, Thailand, a previously remote, inland mid-size city with a deep and rich history, which has experienced rapid growth coinciding with the four-decade time frame of the emergence of the metacity. A modern leisure, tourist, retirement, agricultural, craft and design economy comprises a dynamic landscape of diverse patches. The specifics of a case study will aid in conceptualizing a future metacity practice based on a layering and recombination of all theories of urban form in order to establish a methodological description of a system of systems. Old false dichotomies between rural and urban, center and periphery will be dropped. Borrowed from Western industrial development paradigms, urbanization now of- ten arrives through intensive road, energy and water infrastructure. A metacity practice would trigger adaptive strategies employing tomorrow's rather than yesterday's infrastructures based on self-reliance, environmental responsibility and social cooperation.

\section{Chiang Mai Case Study}

\subsection{Geology, Climate and Early Settlement}

When the India plate collided with the Eurasian continent 90 million years, its subduction produced the $\mathrm{Hi}$ malaya Mountains and Tibetan Plateau. The collision created the headwaters of Asia's great Yellow, Yangtze, Red, Mekong, Irrawaddy and Ganges/Brahmaputra rivers, and the sustenance for Asia's wet rice cultivating civilizations (Figure 2; Marshall, 2016). The impact of this enormous continental collision elongates Southeast Asia southeastward and induces a counter-clockwise rotation (Rhodes, Pereza, Lamjuanb, \& Kosuwanb, 2003). The Irrawaddy and Red River faults bracket a large territory of mountains and valleys of upland Southeast Asia, providing the homeland of the Tai linguistic groups within this rugged terrain forming the frontier between northern Burma, Laos, Southwest China and Thailand. The Ping and Uttaradit Faults funnel a tributary river system comprised of the Ping, Wang, Yom and Nan and their tributaries, the headwaters for the Chao Phraya, Thailand's "River of Kings".

Northern Thailand's highlands and fertile river valleys comprises a distinct human ecology: the hideaway for the anarchic upland tribal groups who practiced what James Scott (2009) has called "the art of not being governed", and the Lanna people who settled the fertile basin areas of fan terraces and lowland alluvial plains of the Ping, Wang, Yom and Nan River Valleys. Ancient records indicate that a communal irrigation system for rice cultivation called muang (canal) fai (weir) has been operating for more than 1,000 years (Surarerks, 2006). In the muang fai system, villagers work collectively to build enormous weirs across the main rivers at the start of the rainy season, diverting water to major irrigation canals several kilometers long, which, in turn feed village based tributaries. The tops of the bamboo and mud weirs wash away once the paddies fill. The muang fai system relies on organized village labor collectives to construct the green infrastructure to capture monsoon rainwater and use the natural gravitational flow of the river to fill their individual rice paddies. The territory still bears clearly visible traces consisting the small landholdings, village networks along with this complex weir, canal and paddy system (Cohen \& Pearson, 1998).

India's cultural influence gave rise to a mandala tributary political system across Southeast Asia that allowed for both large-scale irrigation, road infrastructure and royal city building, while allowing local autonomy in village and inter-village water management. The Dharma Raja was a god of the water, forest and soil; a spiritual leader mediating between heaven and earth. Un- 


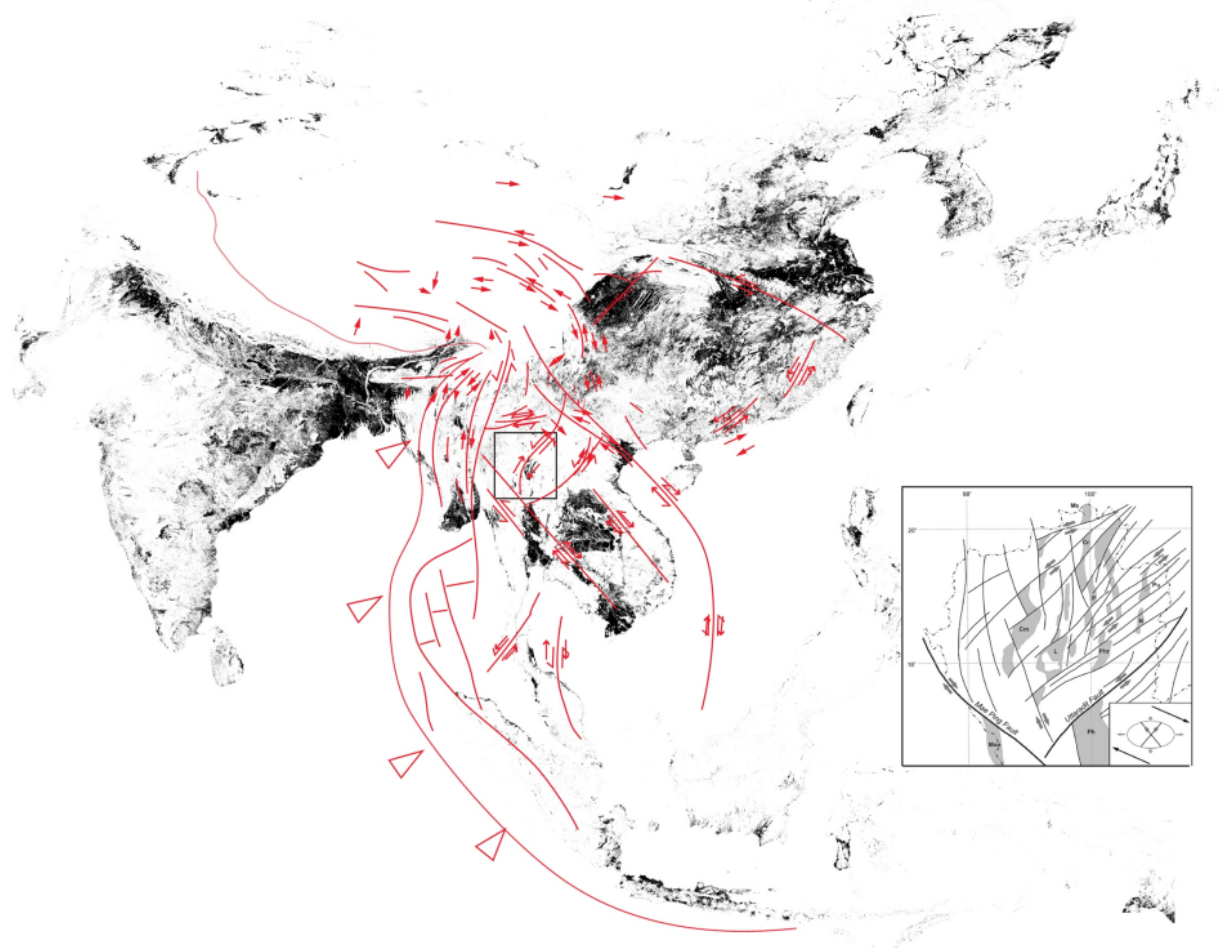

Figure 2. Overlay of tectonic activity created by the subduction of the India under the Eurasian plate in red with areas of rice cultivation in black. Asia Rice map: Andrew Nelson, Murali Krishna Gumma. A map of lowland rice extent in the major rice growing countries of Asia. 2015, 37p. IRRI, Los Banos, Philippines. Inset map of northern Thailand showing the model of Polachan et al. (1991). Shading marks the location of the major basins of northern Thailand within the funnel created by the Ping and Uttaradit Faults.

like the Chinese imperial system, the mandala network produced remarkable differentiation between kingdoms (Coedes, 1966). Phya Mangrai, Lord of the Lanna Kingdom of Northern Thailand, founded his new capital of Chiang Mai in 1296 as a node within this network. Lanna means one million (lan) rice fields $(n a)$, and Mangrai located his capital in the foothills of Doi Suthep to the west for its capacity to guarantee large quantities of water for wet rice cultivation in the lower basin flood plain as well as avoiding flooding (Figure 3). His new royal and religious capital maintained an identity as a distinct sovereign kingdom by providing tribute to the kings in Siam and Burma while commanding lesser kingdoms across the Lanna region (Winichakul, 1994). Mangrai formalized the existing village based muang fai territorial network through issuing the irrigation law known as "Mangrai Sart" or "Winitchai Mangrai". Mangrai's dynasty continued through 1558, when the Kingdom was defeated by Burma. In 1775 Chiang Mai came under control of the King of Siam (Surarerks, 2006).

The Mandala urban form of royal city centers and lesser peripheral centers constituted a tributary ecology as well as a political system for the Lanna region. The system was challenged by colonial demands for metropolitan political system with national borders and legal rights for foreign traders (Winichakul, 1994). Facing the British in Burma and Malaysia and the French in Laos, Cambodia and Vietnam, the Siamese and later Thai state transformed from tributary to a semi-colonial control over the Lanna Kingdom at the turn of the $20^{\text {th }}$ century. To counteract British influence, Siam's King Rama V connected Chiang Mai to Bangkok with a rail line in 1923, a huge financial investment. Most economic development in Siam/Thailand was focused on the primate city of Bangkok with its rice producing and industrial periphery, leaving the Chiang Mai relatively unchanged until the last decades of the turn of the $21^{\text {st }}$ century.

\subsection{State Modernization and Ethnographic Studies}

Thailand benefitted economically from its Cold War alliance with the U.S. during the American War in Southeast Asia, and since the 1970s it became the site of offshoring of Japan's automobile and electronics industries. From the mid 1980s to the mid 1990s, Thailand was the world's fastest growing economy, before the Asian economic crisis of 1997 and China's subsequent domination of global export manufacturing (Pongpaichit \& Baker, 1998). By the 1980s, national policy began to begin some development to the secondary cities of the 

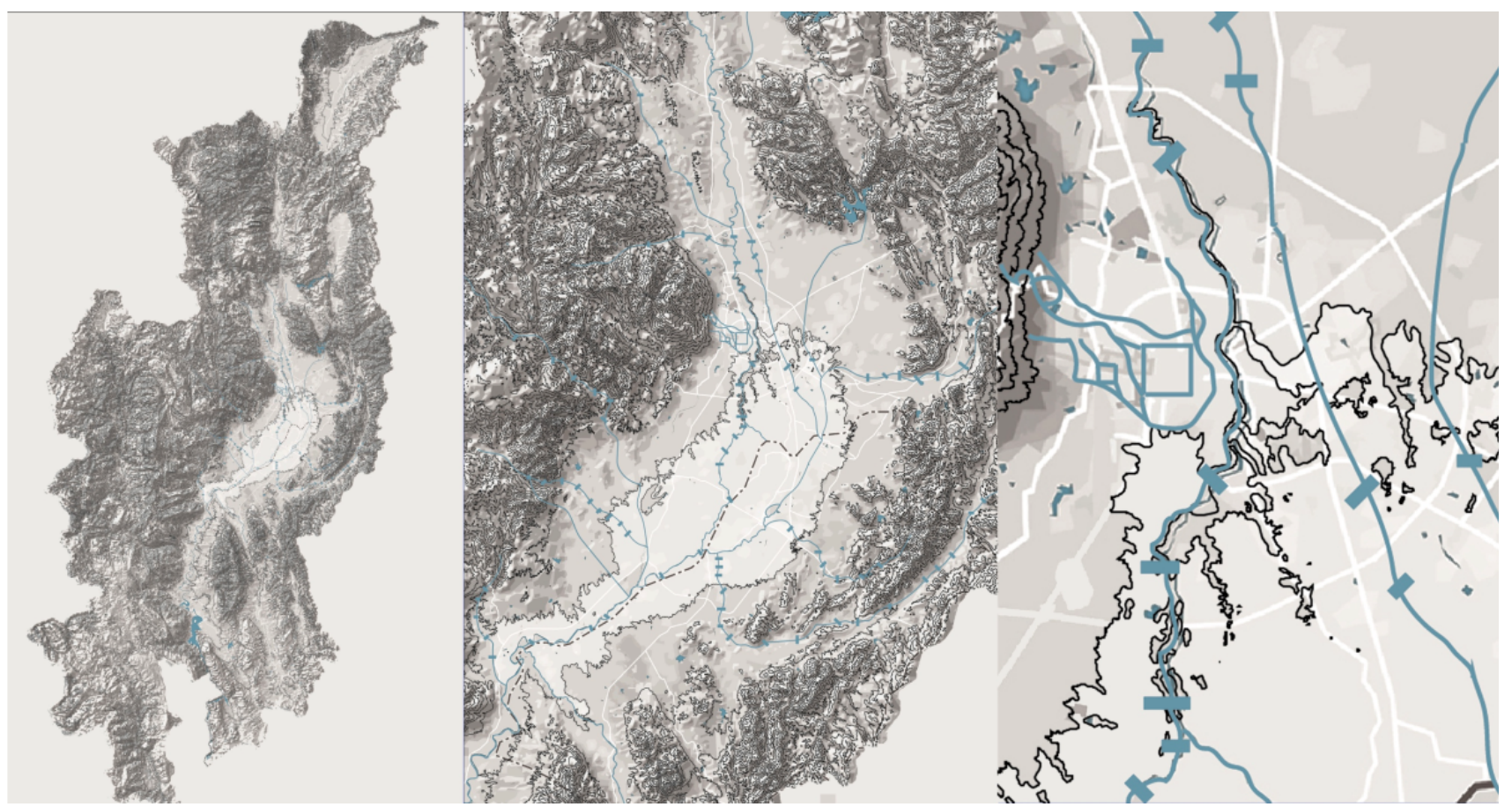

Figure 3. Three scales of the Chiang Mai-Lamphun Valley, a stomach-shaped valley with the royal moated city of Chiang Mai situated at a slightly higher table at the foothills of Mount Suteph, overlooking a lower flood plain southeast of the city. The water supply from the mountain to the old city is redrawn from the research of Surapon Dumrikul. Also shown are the major rivers and community managed weirs documented by P. T. Cohen and R. E. Pearson.

kingdom. Due to the Asian economic crisis of 1997, however, Thailand's GDP shrank from 182 to 112 billion dollars. The economy recovered in 2000 with a $5 \%$ growth through 2007. But deep division about the nature of that recovery has led to continual political unrest, military coups in 2006 and 2014, and current growth most recently under $2 \%$.

Some of the most valuable information regarding the recent urban transition of the Chiang Mai region is found in village anthropological studies conducted since the 1950s. Ethnographies reveal both the ancient muang fai communal farming labor exchange system, and since the 1980s, the impact of modern irrigation and farming technologies, access to labor markets and urbanization. Long term comparison of ethnographic studies present not just the traditional social ecological methods of settlement, but also the transformation of the landscape during contact with colonialism and capitalism. Historical records and important longitudinal comparisons of ethnographies include Peter Cohen's field work from 1967 to 1969 and follow-up research in 1978 and Shigeharu Tanabe's field work in 1974 through 1975 in Mae Rim, $15 \mathrm{~km}$ north and upstream of the city (Tanabe, 1994). Konrad Kingshill (1991) studied a village south and downstream near Saraphi first in 1957 followed by Jack and Sulamith Heins Potter field work in the same village downstream from 1971 to 1972 (Potter J., 1976; Potter S. H., 1980). Tanabe's study of a village in Mae Rim documents village networks as social system employing "practical ecology". Both Tanabe and Jack Potter provide re- markable drawings, diagrams and tables documenting village based, comparative, and multi-village irrigation networks that provide a baseline to evaluate current household and farm structure and management (Figure 4).

Anan Ganjanapan in his field work from 1980 to 1981 first recorded the transformation of the village society due to contacts with modern state Royal Irrigation Department projects (Ganjanapan, 1984). Historian Vanpen Surarerks (2006) provides both the archival evidence of the long history of the communal irrigation system, as well as the introduction of the People's Irrigation Act of 1939 , when the ancient muang fai system is recognized by the Royal Irrigation Department. Mark Andrew Ritchie's field work in the same village as Tanabe from 1990 to 1991 at the beginning of intensive urbanization and modernizations by the state and a new real estate market. Local adaptations play out as villagers' response to contact with Chiang Mai's developing labor and land markets (Ritchie, 1996).

The Ministry of Interior began the first formal planning regulation according to the Town and Country Planning Act in Thailand in 1952 in response to rapid economic growth and the need for urban development control in Bangkok. The modern era of land use planning started following an agreement for technical assistance from the American government that provided scholarships for Thai planners to study and train in the U.S. and they applied knowledge in American land use planning system (Roachanakanan, 2014). American land use planning is based on dividing and classifying blocks and plots 


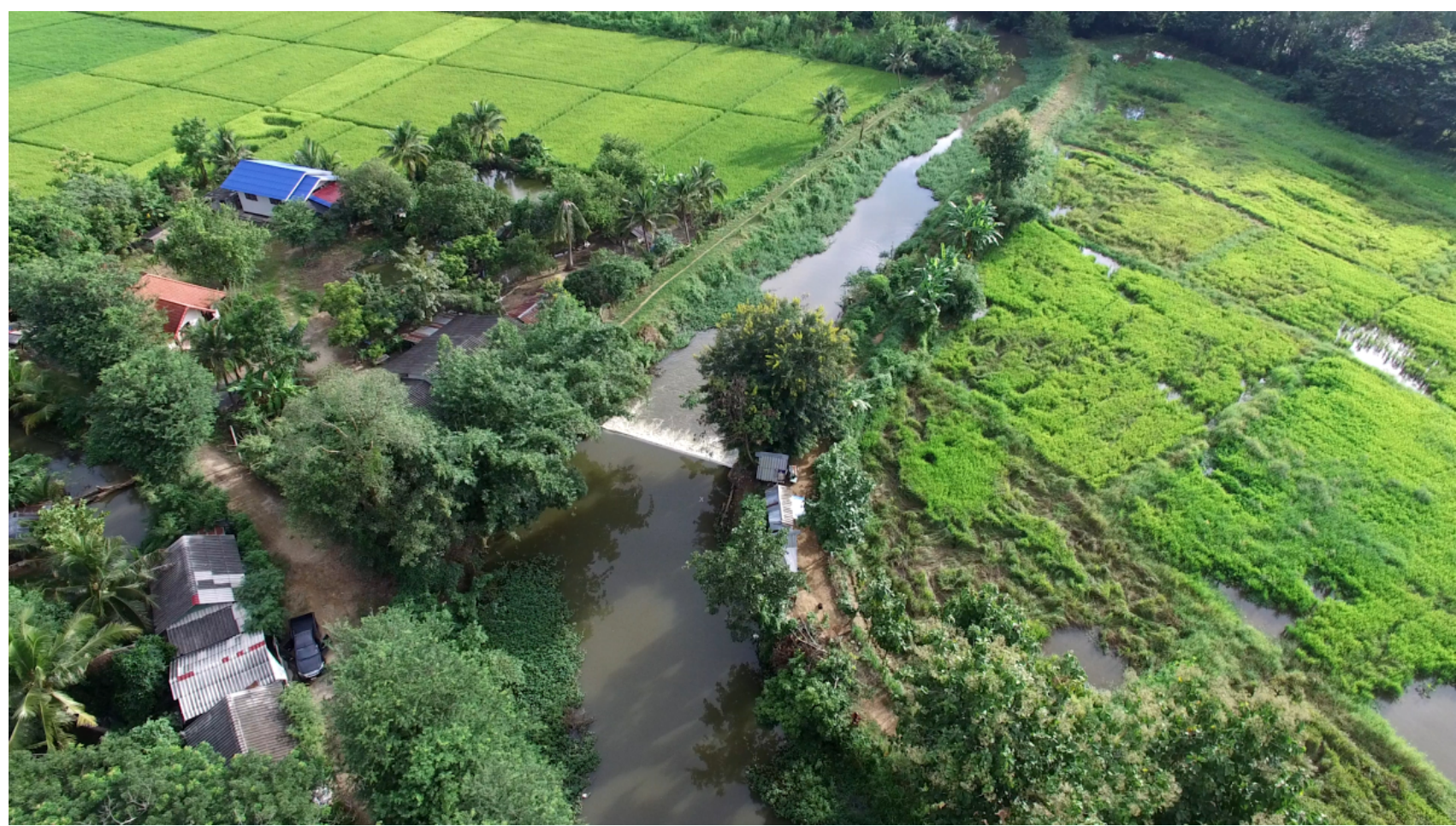

Figure 4. Muang (canal) fai (weir) on the Kuang River inside Chiang Mai's outer ring road. The weir in the center of the image creates a retention pond at a higher level that supplies the canal on the left of the frame, which in turn gravity-feeds the rice paddies in the upper left of the frame. The cultivated rice paddies on the left are on the east side of the Kuang River within the agricultural protection zone, however the ring road is just out of the frame to the left. The unmaintained paddy on the right is within the low-density housing zone west of the river. Drone imagery Santipab Sonboom, October 2016.

of land into different category according to their different functions was not formalized in a land use map in Chiang Mai until 1984.

Sanay Yarnasarn (1985) attended Columbia University on a government scholarship in the 1980s, where he was introduced to three theoretical city models from North American urban geography: concentric zoning, radiating sectors, and multiple nuclei satellites, through which he attempted to analyze the existing land-use pattern as a basis to project the future urban growth of Chiang Mai city following standard practice in North America. Despite the Western conceptions embedded in these models, tools and plans, Chiang Mai's urban-agricultural hybrid mix resisted all these rigid and abstract classifications. The introduction of Western planning strategies, technology and methods fed by central government investments in modernization, led to the inevitable adaptation of Chiang Mai to Western ideas and patterns (Figure 5; McGrath, Barcelloni Corte, \& Sangawongse, 2012).

\subsection{Mapping Rapid Urbanization}

The Ministry of Transportation and the Department of Rural Roads are two Bangkok-based bureaucracies set to determine Chiang Mai's urban future. A flurry of highway building projects followed Thailand's economic boom, and has accelerated the extended urbanization of Chiang Mai. The financial crisis of 1997 divides this road infras- tructure development into two periods in Chiang Mai, with the construction of superhighway and radial road widening before crash producing some rural property development including exclusive golf course communities as well as more modest extensions of villages and towns. The post-crash $21^{\text {st }}$ century city has seen the development of a ring road system and the proliferation of mass market gated communities and new commercial centers. The uneven development of Chiang Mai can be seen as the result of a boom and bust cycle in Thailand, which has lifted the majority out of poverty but has further concentrated wealth.

A team from the Faculty of Social Science at Chiang Mai University and the Chiang Mai Royal Irrigation Office (Region 6) acquired Landsat Thematic Mapper (TM) data and Enhanced Thematic Mapper (ETM Plus) data at $30 \mathrm{~m}$ resolution for 1989, 2000, 2006 and 2009 in order to come to grips with documenting Chiang Mai's rapid urbanization. Data was organized by the supervised classification (Jensen \& Im, 2007) into seven land use types as shown in Table 1. Land use data was one input into a computer model covering the area within the comprehensive boundary to capture the urban growth pattern and to predict future land use change through 2030 . Evidence revealed a significant increase of urban area during the study period (from $10.6 \%$ in 1989 to $18.27 \%$ in 2009). Five different types of growth were modeled: diffusion, breed (city center expansion), spread (expension 


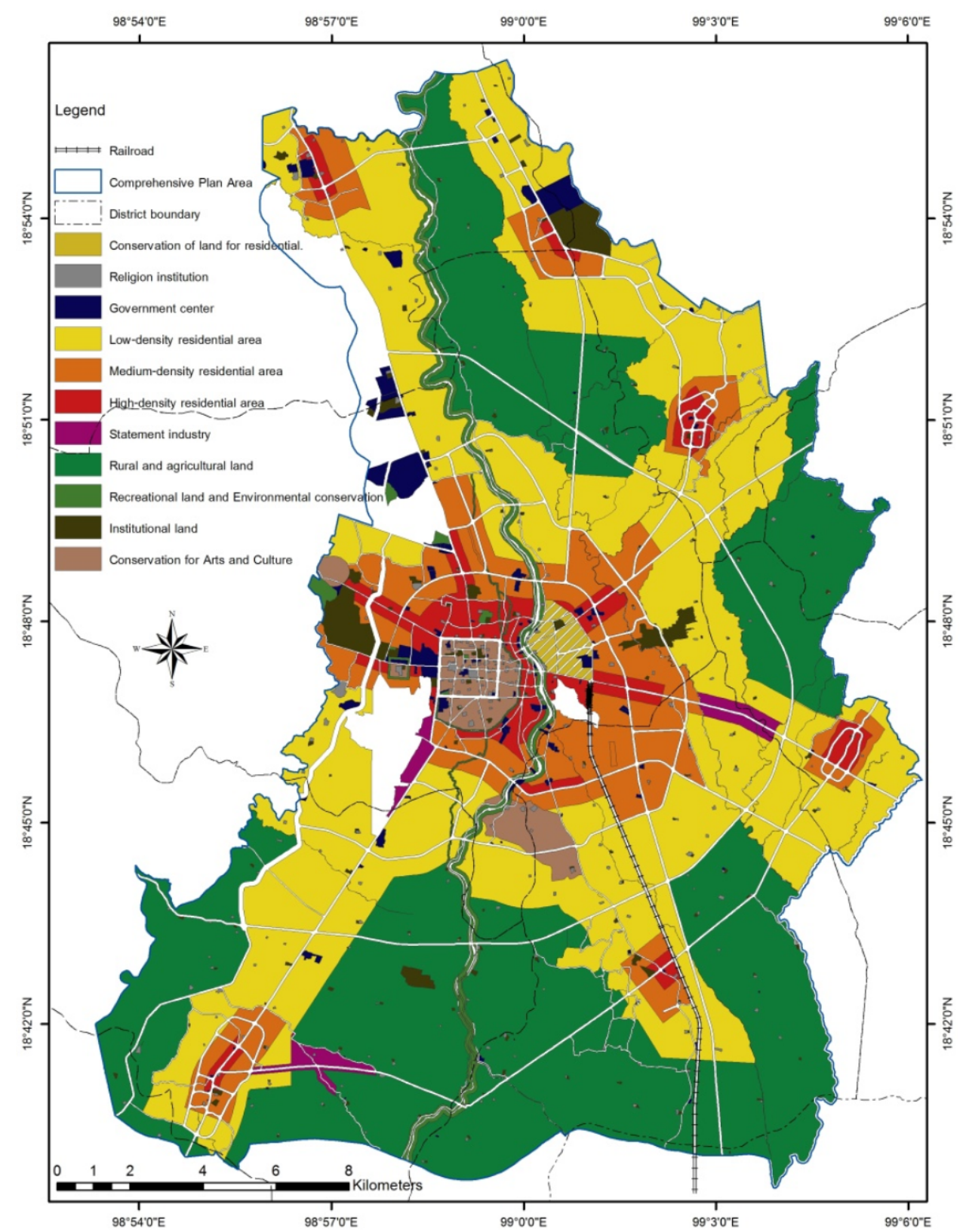

Figure 5. Eleven land use zones in the 3rd revision of the Chiang Mai Comprehensive Plan. The outer ring road passes through wedges of agricultural conservation zones, yet is triggering uncontrolled development. Six older town centers are planned for higher density development along radial roads, but most high density residential and commercial spaces are emerging at the intersections of the superhighway and ring roads and the radial roads producing unplanned centers. Adapted from Department of Public Works and Town \& Country Planning (2010).

from center and sub-centers), slope, and road based. The model predicted a significant increase in proportion of urban area primarily from city center breed and road based development, within the comprehensive planning boundary in five year intervals from 2010 to 2030 with an increase in urban land from $38 \%$ to $80 \%$ (Figure 6; Sangawongse, Sengers, \& Raven, 2012).

But actual urbanization has exhibited all growth types in the SLEUTH model, as evidence of dispersed and sub-center growth is evident from both on the ground and drone surveys, as well as from remote sensing analysis. The valley has seen a great reduction in rice paddy land use over the twenty-year period from 1989 to 2009, first as orchard cultivation replaced rice farming in the 1980s, and after the 1980s, an acceleration of urbanization. The current balance in the comprehensive planning area between forest, orchard, paddy and urban land uses suggests the possibility of seeding a more dispersed and mixed urban/rural development in the future, as opposed to the current road and expanding center models (Table 1 and Figure 7).

Further work on land use change analysis in the Comprehensive Plan boundary was conducted by Sangawongse and Vittaya (2015). This analysis updated the 


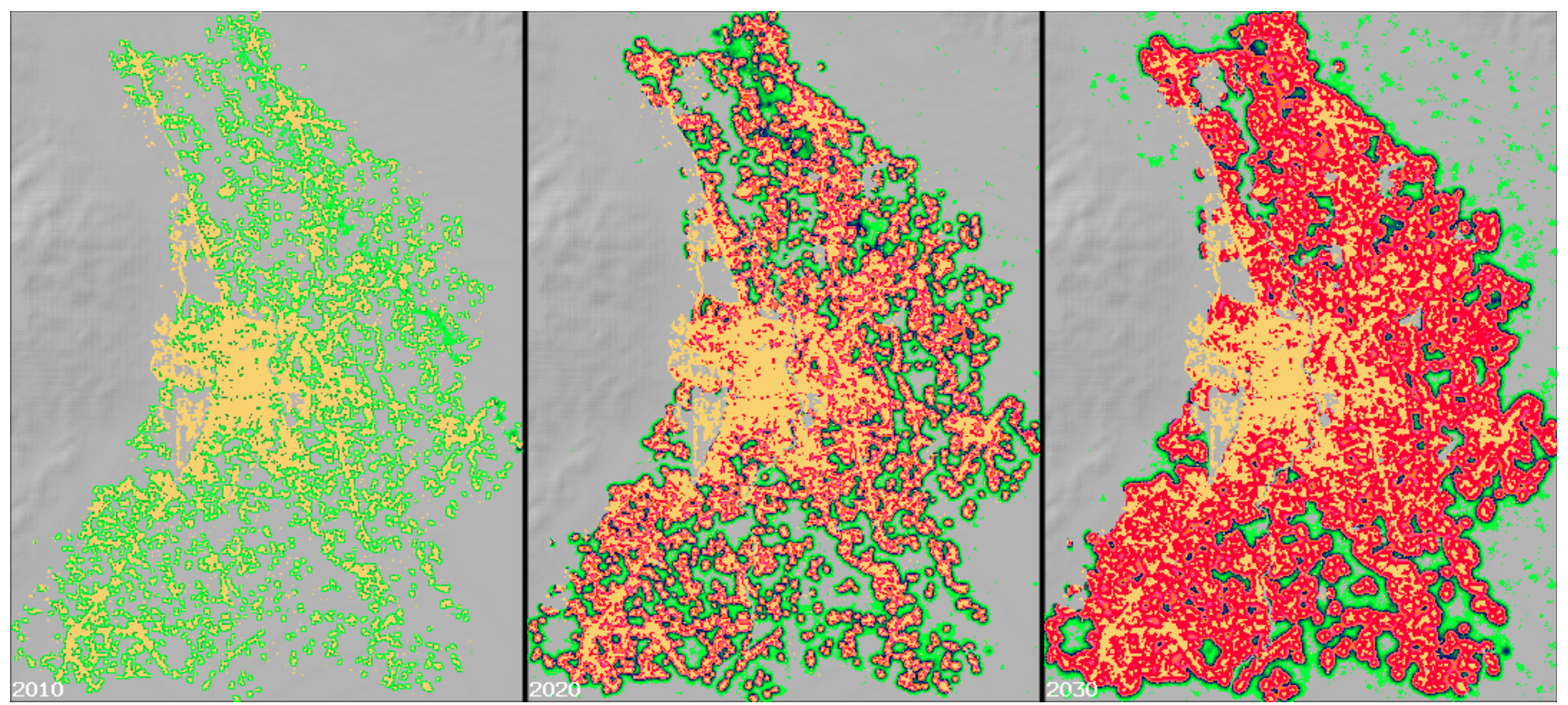

Figure 6. SLEUTH growth model was developed from cellular automaton (CA) model, which can be used for mapping urban growth and land use dynamics. Left, 2010 urbanized area, middle 2020 projection and right 2030 . Without any policy shift, the model predicts $80 \%$ urbanized comprehensive planning area by 2030 (Sangawongse, Kowsuvon, \& Sasom, 2011).

Table 1. Land Use Change in Chiang Mai Comprehensive Plan boundary. From a paddy dominated region to one in which patches of forests, orchards, rice paddies and urban land use interact (Sangawongse et al., 2011).

\begin{tabular}{lrrrrrr}
\hline & \multicolumn{2}{c}{ Area 1989 } & \multicolumn{2}{c}{ Area 2000 } & \multicolumn{2}{c}{ Area 2009 } \\
\cline { 2 - 7 } Land Use Type & \multicolumn{1}{c}{$\mathrm{Km}^{2}$} & \multicolumn{1}{c}{$\%$} & $\mathrm{Km}^{2}$ & $\%$ & $\mathrm{Km}^{2}$ & 12.09 \\
\hline Urban & 73.24 & 10.60 & 83.49 & 26.32 & 18.27 \\
Paddy Field & 283.46 & 41.01 & 201.58 & 29.19 & 131.32 & 18.99 \\
Orchard & 123.04 & 17.80 & 172.15 & 24.93 & 169.62 & 24.53 \\
Forest & 124.91 & 18.07 & 155.67 & 22.54 & 171.92 & 24.86 \\
Water Body & 4.12 & 0.60 & 2.69 & 0.39 & 28.21 & 4.08 \\
Other & 73.36 & 10.61 & 74.31 & 10.76 & 62.88 & 9.09 \\
Bare Land & 9.09 & 1.32 & 0.7 & 0.10 & 1.24 & 0.18 \\
\hline
\end{tabular}

number of new buildings within the Comprehensive Plan boundary up to 2013 using the ortho-aerial photographs of Chiang Mai acquired from the Royal Thai Survey Department in 2013. Changes between 2000 (base year) and 2013 were classified according to eleven land uses in the Comprehensive Plan boundary. Results showed that built-up areas of urban land use categories have increased mostly in low density residential class with $33 \%$ increase in number of buildings and $37.5 \%$ in total area (Table 2). Most significantly, this research revealed that $20 \%$ of growth since 2000 has crossed the land use boundaries within the plan with many subdivisions built within the agricultural zone. Development has also leapfrogged over the comprehensive boundary itself. Meanwhile large areas zoned for residential use remain active farming areas. The entire plain is subject today to an extremely complex condition of urban dispersal, which is strongly changing the ecological and economic mix of the region. As a result of the construction of new roads and urban facilities, a new diffuse and mixed city (McGrath, 2012) is being created.
While the comprehensive plan aims to preserve wedges of agricultural land between the main radial streets, gated housing enclaves are being constructed along both radial and ring roads. The logic of the comprehensive land use plan does not sync with the infrastructural capacities of the irrigation and road systems. A major branch of the Mae Kuang system is used as a border between urban and agricultural land uses, ignoring the fact that it is best suited for agricultural land. The outer ring road crosses large swaths of agricultural preservation zones, while it disrupts the gravity fed irrigation system and promotes development of gated communities. Land use boundaries are not enforced, but bureaucratic boundaries between ministries and between scalar jurisdictions prevent synthetic urban/rural planning and design integration and cooperation.

Clearly the controlled planning strategy promoted by the Ministry of the Interior does not match the reality on the ground in Chiang Mai. A metacity project needs to provide the basis for a new conception of the city and more innovative planning strategies based less 

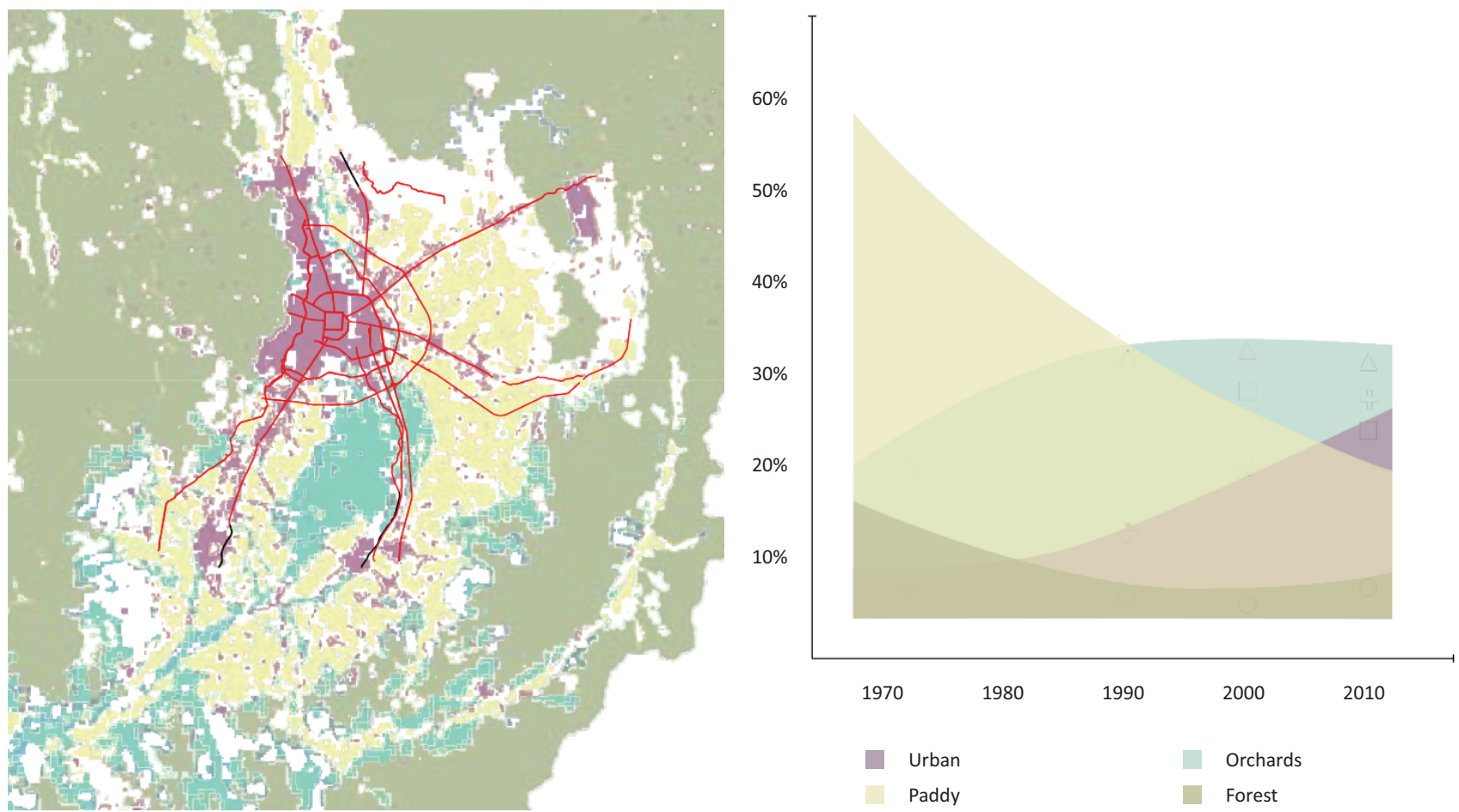

Figure 7. Chiang Mai/Lamphun Valley showing the major land cover types. The graph indicates Sangawongse's land use documentation of the comprehensive planning boundary. A rice paddy and forested dominated region has recently evolved to one where there is a balance between urban area, orchard, paddy and forest patches. Agricultural map underlay adapted from M. Ekasingh, Chiang Mai University Multiple Cropping Center.

Table 2. Land Use Changes in the Comprehensive Plan Boundary by Zones between 2000-2015. Data reveals that 20\% of recent building construction within the comprehensive boundary area has been in agricultural preservation zone. (Sangawongse \& Vittaya, 2015).

\begin{tabular}{|c|c|c|c|c|c|c|c|c|}
\hline \multirow[b]{2}{*}{ Land Use Code/Classes } & \multicolumn{2}{|c|}{$\begin{array}{l}\text { Buildings } \\
(2000)\end{array}$} & \multicolumn{2}{|c|}{$\begin{array}{l}\text { Buildings } \\
(2015)\end{array}$} & \multicolumn{2}{|c|}{$\begin{array}{l}\text { Change in no. } \\
\text { of buildings }\end{array}$} & \multicolumn{2}{|c|}{$\begin{array}{l}\text { Total Area } \\
\text { change }\end{array}$} \\
\hline & $\begin{array}{l}\text { Number } \\
\text { (Thousands } \\
\text { of Units) }\end{array}$ & $\begin{array}{l}\text { Area } \\
\text { (sq. } \\
\text { km.) }\end{array}$ & $\begin{array}{l}\text { Number } \\
\text { (Thousands } \\
\text { of Units) }\end{array}$ & $\begin{array}{l}\text { Area } \\
\text { (sq. } \\
\text { km.) }\end{array}$ & $\begin{array}{l}\text { Number } \\
\text { (Thousands } \\
\text { of Units) }\end{array}$ & Percent & $\begin{array}{l}\text { Area } \\
\text { (sq. } \\
\text { km.) }\end{array}$ & Percent \\
\hline 1. Conservation residential use & 2.00 & 0.39 & 2.20 & 0.60 & 0.20 & 1.66 & 0.21 & 1.08 \\
\hline 2. Low density residential zone & 4.76 & 6.99 & 8.71 & 14.23 & 3.95 & 33.01 & 7.24 & 37.51 \\
\hline 3. Medium density residential zone & 2.52 & 4.66 & 3.46 & 6.70 & 0.94 & 7.85 & 2.04 & 10.55 \\
\hline 4. High density residential zone & 12.39 & 0.31 & 15 & 4.09 & 2.17 & 18.10 & 3.78 & 19.57 \\
\hline 5. Specific Industrial zone & 1.63 & 0.44 & 2 & 0.61 & 0.34 & 2.84 & 0.18 & 0.91 \\
\hline 6. Rural \& Agricultural zone & 3.60 & 3.68 & 5.2 & 7.53 & 1.64 & 13.67 & 3.85 & 19.94 \\
\hline $\begin{array}{l}\text { 7. Open space for recreation \& } \\
\text { maintaining environmental quality }\end{array}$ & 4.88 & 0.08 & 5.5 & 1.07 & 0.65 & 5.46 & 0.99 & 5.11 \\
\hline 8. Educational land use & 1.90 & 0.85 & 2.4 & 1.18 & 0.47 & 3.91 & 0.33 & 1.72 \\
\hline 9. Preservation of cultural identity & 9.13 & 1.66 & 10 & 2.05 & 1.18 & 9.81 & 0.39 & 2.02 \\
\hline 10. Religious institutions & 2.37 & 0.47 & 2.6 & 0.61 & 0.28 & 2.31 & 0.14 & 0.75 \\
\hline $\begin{array}{l}\text { 11. Government Institutions and } \\
\text { public utilities }\end{array}$ & 2.89 & 0.78 & 3.1 & 0.94 & 0.17 & 1.39 & 0.16 & 0.84 \\
\hline Total & 48.07 & 20.31 & 60.05 & 39.61 & 11.98 & 100.00 & 19.30 & 100.00 \\
\hline
\end{tabular}


on hypothetical models, and with more analysis understanding of the discrepancy between the comprehensive land use plan which designates agricultural preservation wedges, and ring road construction through those supposed preservation zones. With the rise of Edge Cities in the U.S. in the 1980s, economics developed spatial models for the self-organization in space along lines (strips or ribbon developments) and rings, punctuated in time by waves of development (Krugman, 1996). These models perfectly describe the two phases of the last four decades of development in Chiang Mai, which coincide with the development of a radial and ring road system. The geographic data looking at land use change from 1989 to 2009 shows the current balance between forest, orchards, rice paddies and urban land use, while the second data set demonstrates the effect of radial and ring sprawl.

\section{Conclusion: Study Areas for a Metacity Project}

\subsection{Current Urban Reality on the Ground}

Two extensive surveys of study areas in close detail have been conducted, first in the orchard dominated area south of the city, studied in 2012 (Barcelloni Corte, 2014), and current field work by McGrath east of the city center. The area around Saraphi, downstream of the old city center of Chiang Mai, is the best irrigated land in the region, and farmers have profited from switching to longan and other fruit orchards in the early 1980s with government support (Figure 7). Barcelloni describes the traditional settlement area as consisting of diverse patches, often separate from each other physically, functionally, economically and in terms of age, but imbued with great flexibility, easily modifiable, adaptable to the changing needs of the different subjects they come under. Alongside the minute mixture of functions in small urban centers sit market streets, where homes and shops, mechanics, and small factories cohabit side-by-side, within a cultivated area that has come to be dominated by commercial orchard farming.

Large plots of longan trees stretch in between villages, tucked in areas removed from recent highway construction and their attended gated communities. Agricultural, industrial and residential uses are not separate but work, trade, services and leisure coexist within a complex urban/rural matrix. Spaces of everyday living appear like complex tesserae within a great territorial mosaic of extended villages, religious buildings and spaces, factories and industrial warehouses, as well as small and medium centers, inside a common territorial frame. The research offered an analysis of the site as an example of "horizontal urbanism" that integrates the rich mixture of flexible housing patterns, combined residential/work environments, with emerging forms of commercial concentration and public life (Barcelloni, 2014).

San Phu Loei, a town in Doi Saket District $15 \mathrm{~km}$. east of Chiang Mai, is within the Chiang Mai Comprehensive
Plan boundary. Here the new outer ring road intertwines with the Mae Kuang River, feeding a landscape dominated by wet rice paddy cultivation. Bisecting this intertwining river and highway is the narrow, old San Kamphaeng Road, the "handicraft highway" developed for bus coach tourism in the 1980s (Cohen, 1995). Erik Cohen identifies two types of craft-ribbons: the simple localized ribbon, emerging along roads in and adjoining a craft producing community, and the complex ramified ribbon which emerges between such a community and a major urban tourist center. Ban Tawai wood carving village south of the city center and the Bo Sang bamboo and mulberry paper umbrella making to the east are examples of the former, while Hang Dong to the south and San Kaphaeng Road to the east are examples of the latter (Figure 8).

These older radial roads not only fostered new craft industries to serve bus coach tourism, but also facilitated the development of a first phase of housing subdivisions before the financial crisis of 1997, when much speculative real estate development fell into bankruptcy. As a result, radial roads from the city center connect to multiple incomplete and partially vacant subdivisions located between villages, rice paddies and new gated communities. Large tracks of rice paddy and vacant land are preserved within the super blocks created when the new ring roads crossed the older radials at the end of the $20^{\text {th }}$ century. The urban low density yellow zone of the comprehensive plan contains many productive rice fields and orchards, while patches of new property developments proliferate within the agricultural preservation zone. Illogically, the Kuang River forms the border between yellow residential and green agricultural zones, when it is the main conduit for paddy irrigation and the life line of a rich agricultural zone within the outer ring road. (Figure 9). Both study areas share common opportunities and challenges to the current urban plan: creating a new village compound, fostering new craft economies, and finally designing a new public realm.

\subsection{The New Village Compound}

In both sites, village compound houses are structured to accommodate intergenerational matrilocal extended families (Potter, J. 1976; Potter, S.H. 1980) confront a new landscape of gated subdivisions filled with identical detached houses on small plots built for an imagined nuclear family consumer. Ethnographic studies conducted over several decades reveal how the compound house accommodated an open relation between interior and exterior spaces and evolves through simple additions of extended family dwellings, work spaces and outdoor living areas and kitchens. These compounds create tree shaded microclimates, and now increasingly include small business enterprises and small dormitories. The expanded compound now often provides the only affordable housing for migrant laborers and spaces for small cottage industries serving the urban economy. 


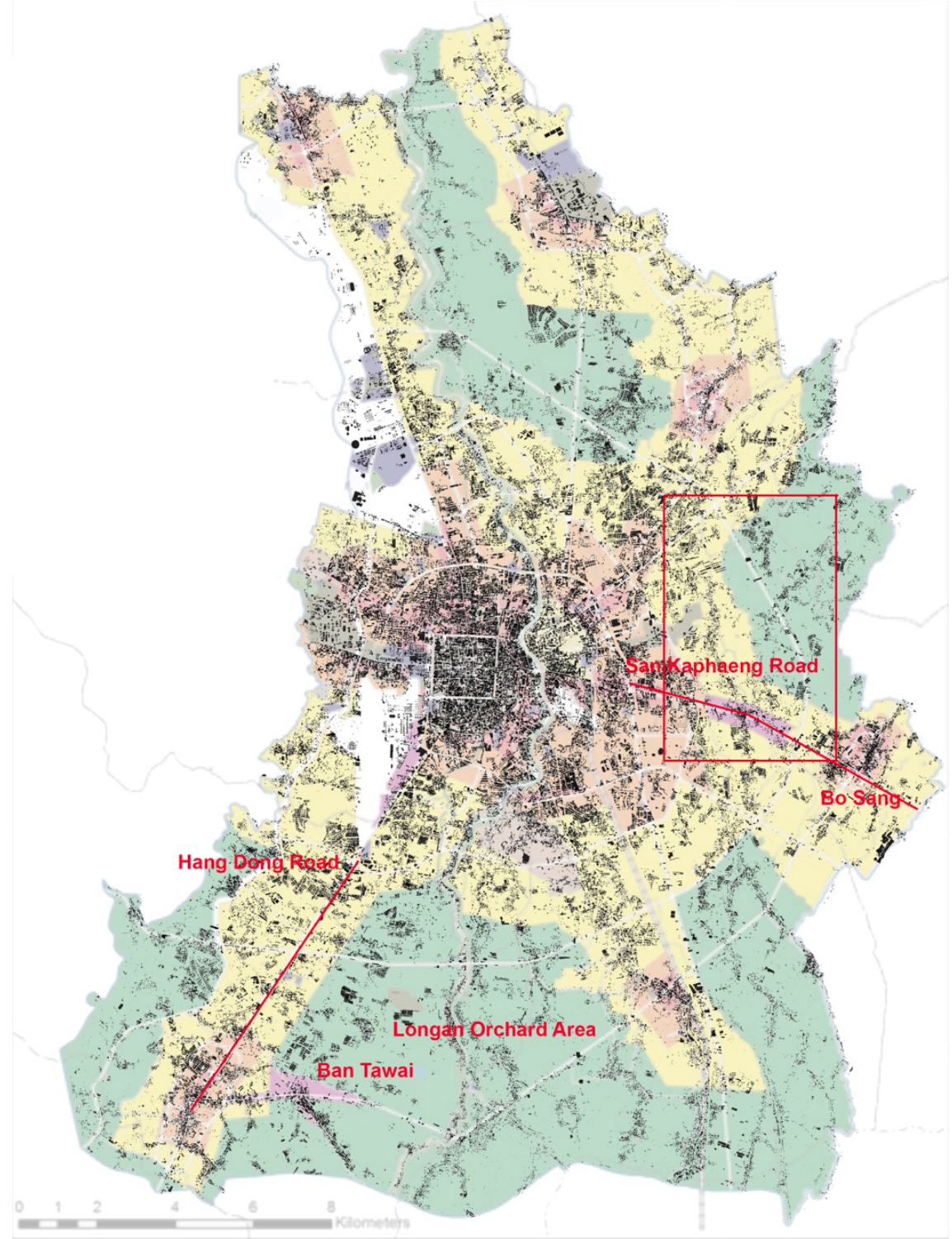

Figure 8. Figure/Ground drawing of Chiang Mai overlaid on the comprehensive plan area showing the highway induced sprawl overlaying with the existing village/water/paddy structure of the land. Both growing villages and new gated enclaves proliferate within the agricultural preservation zone (green on this map). The inset area outlined in red is the study area illustrated in Figure 9.

In contrast with ring road gated developments, these small-scale initiatives exploit existing resources to produce a pattern that densified and adapted the village with simple modifications. Slight road extensions at villages create new house zones separate from the large gated subdivisions along the new ring and widened arterial highways. The pattern of change in the residential grain of the villages spread across the valley can be detected easily in the time series of Google Maps since 1984. Before the economic crisis of 1997, a first phase of interventions associated with local actors consisted of compound and village densification and extensions through street building and land plotting. A second, postcrisis phase, features more homogeneous interventions, completed built out with limited house types of consistent design developed by large Bangkok-based firms equipped with mortgage plans catering mostly to a nonresident market (Figure 10).

The new real estate enclaves are highly inflexible and ill-suited to the climate, familial needs or even cooking habits of locals. The social value of flexibility confronts the real estate worth of ensuring a safe investment. The new gated enclaves feature a limited pallet of material and layout choices, highly manicured open spaces raised on land fill and fenced behind large concrete walls above surrounding farms. Gated and protected, they guarantee safety and privacy, but at the same time are isolated from the existing natural resources and social infrastructure. The selling point for the house is the view of surrounding rice fields and mountains, but there is little support for the farmers or the communal irrigation infrastructure which maintains that landscape. 


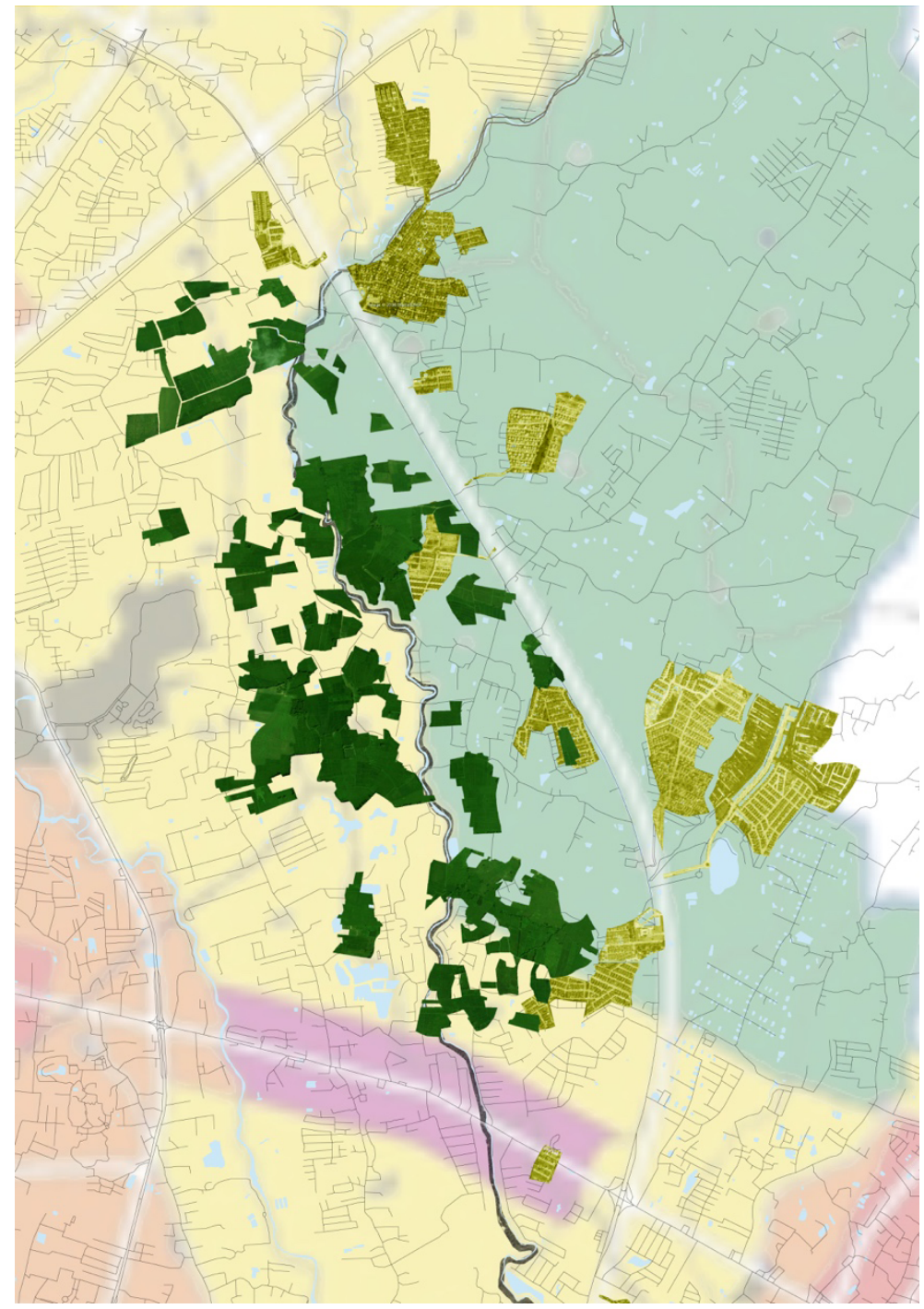

Figure 9. Study area showing the Mae Kuang River and adjacent rice paddies on the left in green and the outer ring road and new gated subdivisions in yellow on the right, overlain on the comprehensive plan zones: yellow is low density housing, green is agricultural preservation and the purple manufacturing ribbon is along San Kaphaeng Road, the "handicraft highway". Collage from Google Earth imagery, December 2016.

\subsection{New Craft Economies}

The handicraft highways serving tourists as well as the food processing industry which accompanied longan cultivation and other market based farming have transformed subsistence farming life to diverse forms of commodified labor. Ethnographers have described the seasonal cycle of rice farming and how villagers in addition to setting up craft production also turn to construction, transportation, tourism and small scale retail to supplement farming income. Single or small groups of industrial sheds are scattered between villages and farm fields. These productive fragments at first sight seem at odds with the agricultural landscape, but a more detailed analysis reveals that villages, farms and small industries are complementary.

Tourism-related craft-producing and marketing establishments took the form of ribbon development for bus coach tourism (Cohen, 1995). However, handicraft was traditionally dispersed within the village and farm compound setting, and many new art, design, food and craft entrepreneurs are seeking out these "rural" locations off the tourist ribbons. Chiang Mai's branch of Thailand Creative and Design Center in bringing new attention to the future of a craft economy tied to global interest in well-designed hand made goods. The co-presence and the mixture of functions between productive, residential and agricultural activities sharing the same services and infrastructure highlights the possible integration of rural and urban types, not as a passing phase as McGee describes in Desakota (1996), but aided by social media and GPS navigation as a new form of metaurbanism. A point cloud of new developments form micro-nodes of a new local production system that has a potential to connect to the search for cultural authenticity and sustainable tourism (Figure 11). 


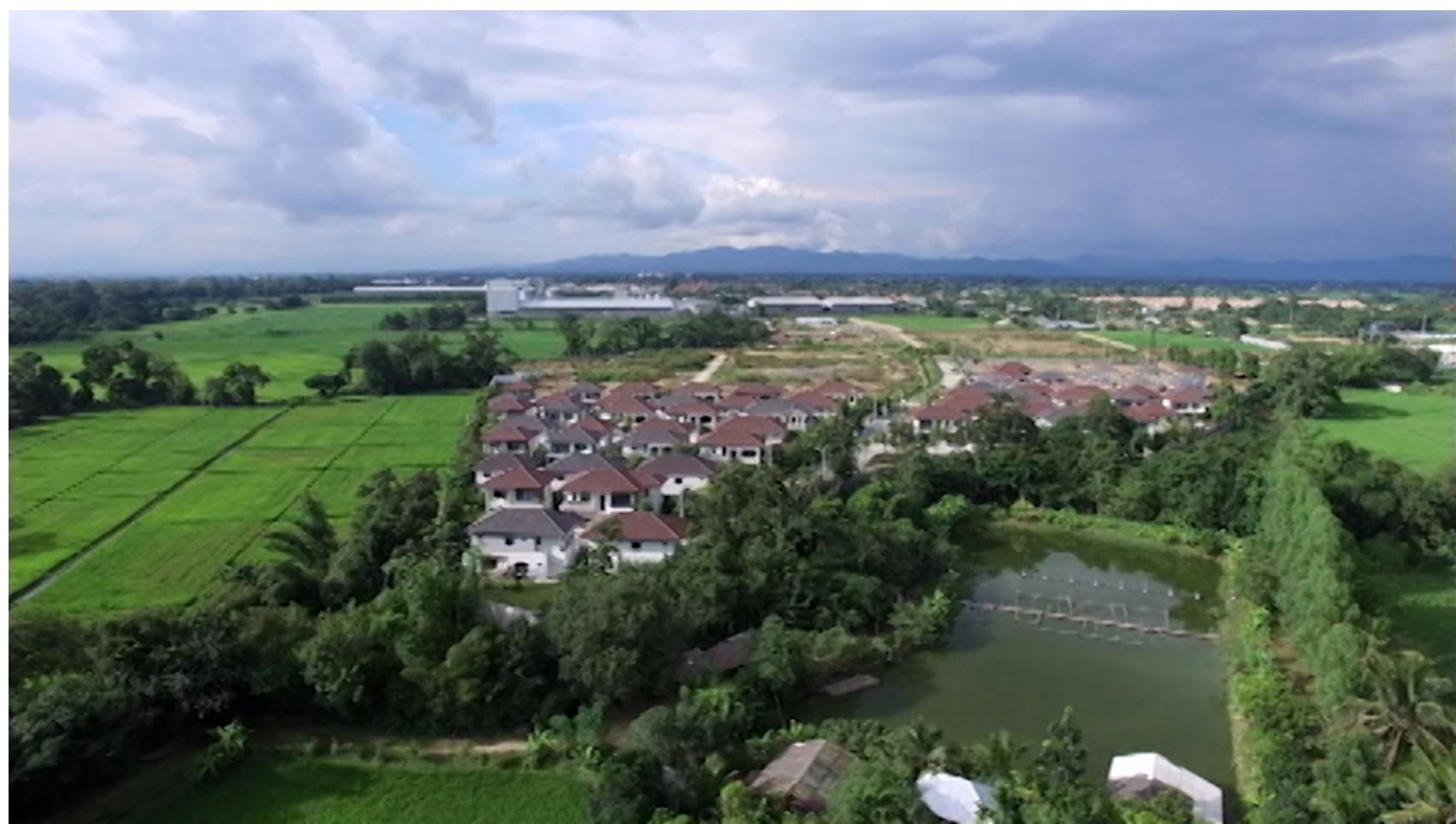

Figure 10. A high wall separates rice paddies and fish ponds from new gated community under construction within the agricultural preservation zone east of the Kuang River. Industrial food processing sheds can be seen in the background. Drone imagery: Santipab Sonboom, October 2016.

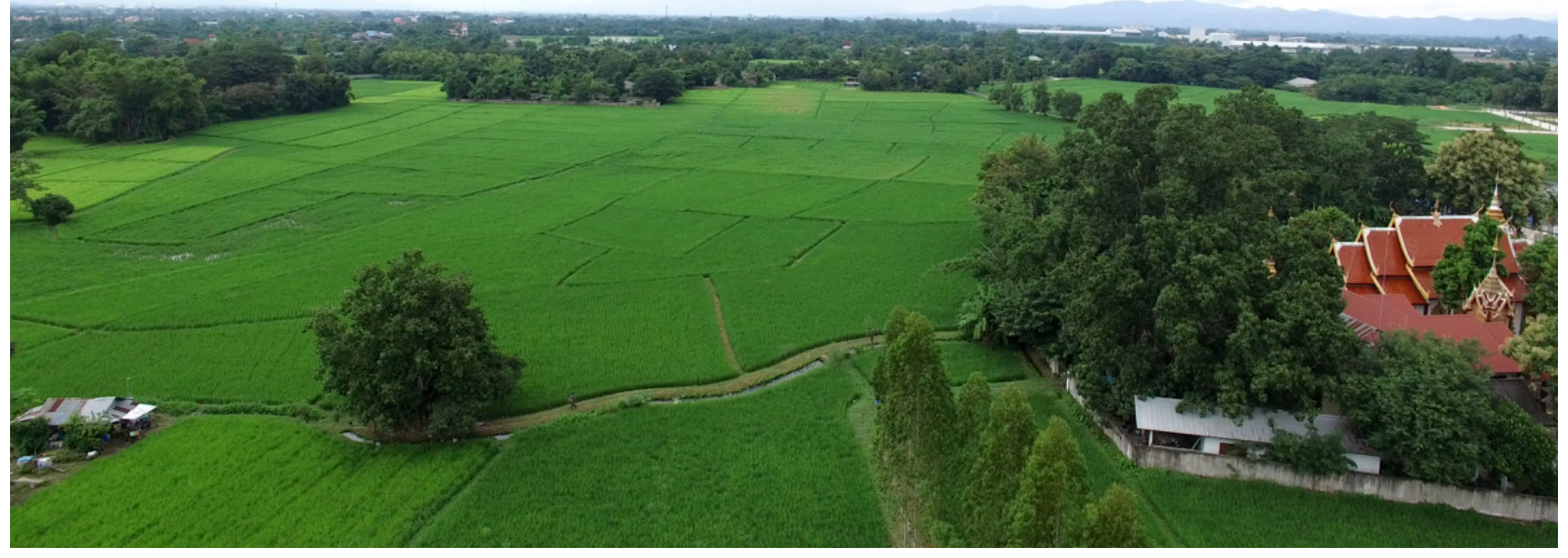

Figure 11. Wet rice paddies and secondary irrigation canals just north of the weir in Figure 12, all within the low density residential zone of the comprehensive plan. Wat Tha Thum is to the right. Drone imagery: Santipab Sonboom, October 2016.

\subsection{A New Public Realm}

While the widening of radial roads triggered linear strip commercial development before the economic crisis of
1997 , the completion of three ring roads by end of the $20^{\text {th }}$ century produced a new gated community residential market, as well as multiple new commercial and high density residential zones. Malls and mid-rise con- 
dominium projects are built across the street from each other, but no pedestrian connection has yet emerged. A proliferation of bicycle advocacy groups and weekend walking streets has created a new interest for a modern public realm and in a public transit system. However, the majority of the area of the valley is an agricultural territory that is only designed for the car between historical city with its temples, wall and moat, and the amenityfilled forested mountains.

Between and surrounding the new highway sprawl an intricate network of streams, weirs, canals and roads forms an undervalued public infrastructure that could provide public access and participation in agricultural life rather than forming a scenic backdrop for the marketing of new homes. This narrow and winding network induces slow movement of bicycles and pedestrians, but also motorcycles, tractors and the informal public transit of pick-up trucks with two benches and small vans. The small weirs and canals are still collectively maintained by villagers, cleaned and flushed according to the seasonal variations of water levels, and marked by spirit houses and seasonal rituals in sync with the monsoon cycle (Figure 12). These artifacts are nodes in the most important public realm of the Lanna territory, and they hold the possibility of not only connecting the villages, but providing access between new dense nodes and incorporating the recently constructed gated enclaves.

These two public investments, one, the state's large infrastructural systems, and the other, the gradual im- provement of the existing pathways and waterways, constitute the overlay of high and slow speed territories. Since these territories do not have a dominant center, a dispersed condition establishes non-hierarchical relationships between their different patterns and speeds. A metacity system whose complementarity and integration, beyond the center-periphery center-center opposition, renders an integrated area where open and agricultural land weaves complex and often complementary patterns and relationships with new developments. The metacity is a layered space evolving towards an increasingly connected mesh where the dispersion of figures creates a dense network of elements providing choice and difference but not leading to the forming of rigid hierarchies.

\subsection{Metacity Practice}

The last four decades of development in Thailand have occurred within the volatile time frame of economic booms and busts, extreme political shifts between populist and royalist sentiments, and extreme flood and draught cycles. Yet, Chiang Mai remains a high amenity area of ecological and cultural importance with great scenic beauty and increasing tourist, leisure, retirement and second home demand. Comprehensive planning favors the system of the main urban center and the routes crossing the territory connecting to mountain's leisure and recreation amenities. Contemporary design practice

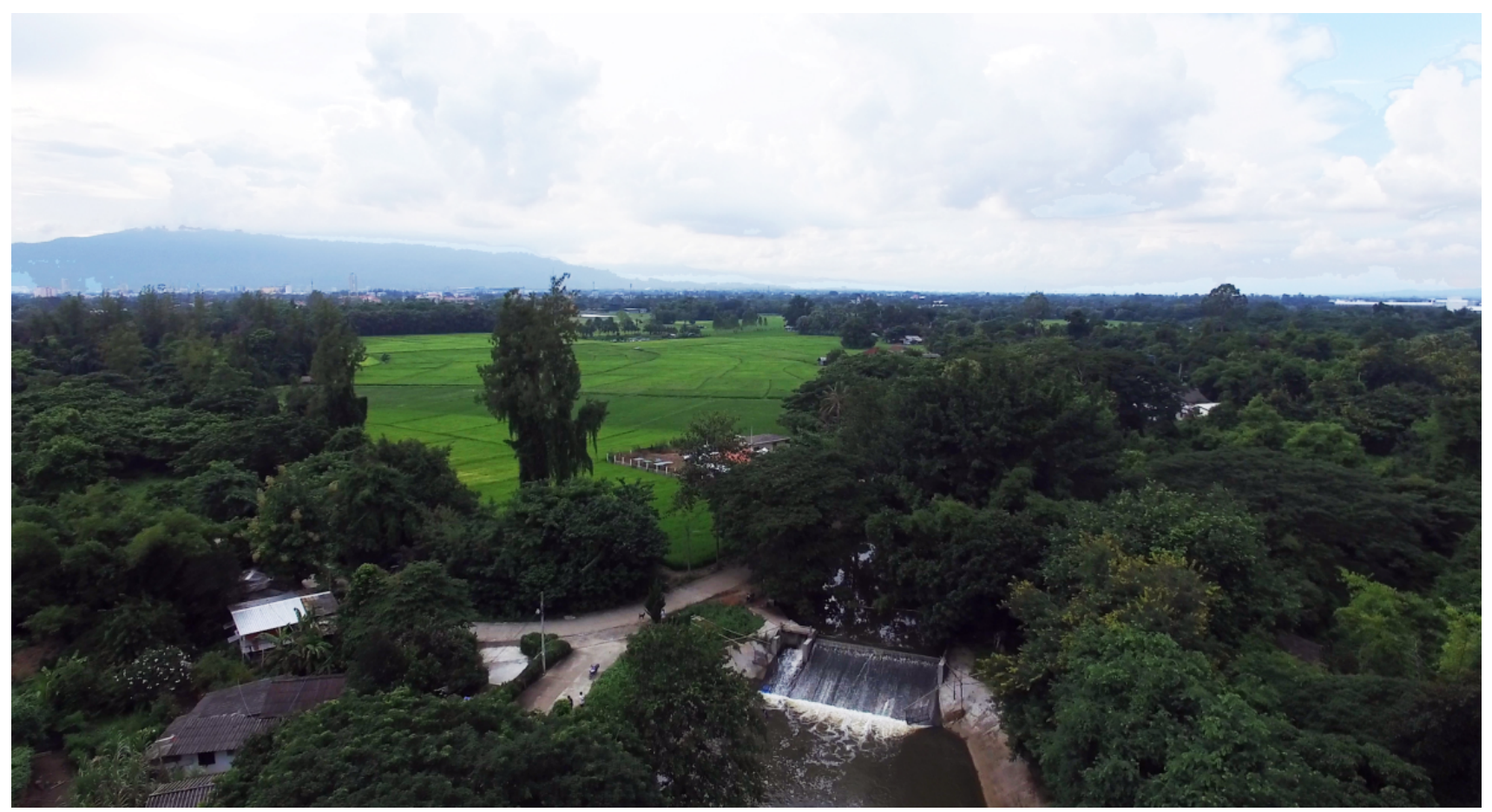

Figure 12. Royal irrigation department people's irrigation project on site of former muang fai looking north with Doi Suthep mountain to the west (left of frame). The weir creates a fish hatchery pond upstream and feeds an irrigation canal following the curving road to the left. The large rice field in the background, fed by the upstream pond. The rice field is within the low-density housing zone as it is east of the Kuang River. The land to the west is zoned for agricultural preservation. Drone imagery: Santipab Sonboom, October 2016. 
has focused on the design and packaging of new architectural products and the successful conservation of the historical center and the forested hinterland, while the agricultural zone of the flood plain in between has been neglected.

The detailed case study of Chiang Mai can be seen as representing the extensive urbanization practice of national infrastructural and real estate products in rural territories across Asia (Figure 1). Rapid and dense road and real estate development has ignored the diverse cultural, spatial and ecological legacies in the extended, densely inhabited traditional networks of wet rice cultivating societies (Figure 2 ). $20^{\text {th }}$ century urban building types and design practices progressively stiffen the territorial ecosystem, making it increasingly less flexible and resilient. The micro-communal irrigation networks and cooperative village settlements in Chiang Mai are important elements of the development and selfdetermination of the regional economy and have not been successfully engaged by governments, architects and urban planners (Ganjanapan \& Lebel, 2014). Current urbanization brutalizes the fragile village/rice cultivation/communal irrigation system through modern dam and canal building and highway construction, urban strategies of a top-down metropolitan panning system of the past.

A metacity practice assists the adaptation of the historical territory to the new demands and desires of a modernizing society, but always begins with a careful analysis of the lived reality on the ground. A metacity project models the calculus of the multitude of individual decisions relative to the best mode of dwelling, working, recreating and living by a territory's residents. A metacity practice reflects the lifestyles of inhabitants who, with time, have learned to make good use of the considerable potential of the natural resources of the valley by utilizing the power of labor exchange and social cooperation (Potter J., 1976) and advocates incremental selfdetermination (Tan-Kim-Yong, 1995).

\section{Conflict of Interests}

The authors declare no conflict of interests.

\section{References}

Banham, R. (1972). Los Angeles: The architecture of four ecologies. New York: Harper \& Row.

Barcelloni Corte, M. (2014). Horizontal urbanism: A comparative exploration of an emergent urban principle from land to water (Doctoral Dissertation). IUAV, Venice, Italy.

Coedes, G., (1966). The making of South East Asia. Berkeley, CA: University of California Press.

Cohen, E. (1995). Touristic craft ribbon development in Thailand. Tourism management, 16(3), 225-235.

Cohen, P. T., \& Pearson, R. E. (1998). Communal irrigation, state, and capital in the Chiang Mai Val- ley (Northern Thailand): twentieth-century transformations. Journal of Southeast Asian Studies, 29(1), 86-110.

Department of Public Works and Town \& Country Planning. (2010). Future land use plan: Scale 1:4000. Bangkok: Department of Public Works and Town and Country Planning (DPT), Ministry of Interior. [In Thai]

Gandelsonas, M. (1999). X-urbanism. New York: Princeton Architectural Press.

Ganjanapan A. (1984). The partial commercialization of rice production in Northern Thailand (1900-1981) (Ph.D. Dissertation). Cornell University, Ithaca, USA.

Ganjanapan S., \& Lebel L. (2014). Interplay between new basin organisations, pre-existing institutions and emerging environmental networks in the Mae Kuang watershed, Northern Thailand. In The politics of river basin organisations, coalitions, institutional design choices and consequences. London: Edward Elgar Publishing.

Jensen, J. R., \& Im, J. (2007). Remote sensing change detection in urban environments. In Geo-spatial technologies in urban environments (pp. 7-31). Heidelberg: Springer-Verlag.

Krugman, P. (1996). How the economy organizes itself in space: A survey of new economic geography. Sante Fe: Sante Fe Institute Working Papers.

Kingshill, K. (1991). Ku Daeng: Thirty years later. DeKalb, IL: Northern Illinois University.

Koolhaas, R. (1978) Delirious New York. New York: Oxford University Press.

Lefebvre, H. (1992). The production of space. New York: Wiley-Blackwell.

Marshall, V. (2017). Designing mega delta interactions. In S. Dong, J. Bandyopadhyay, \& S. Chaturvedi (Eds.), Environmental sustainability from the Himalayas to the oceans: Struggles and innovations in China and India (pp. 205-238). New York: Springer.

McGee, T. G., (1991). The emergence of Desakota regions in Asia: Expanding a hypothesis. In N. Ginsburg, B. Koppel, \& T. G. McGee (Eds.), The extended metropolis: Settlement transition in Asia (pp. 3-25). Honolulu: University of Hawaii Press.

McGrath, B. (2008). Digital modelling for urban design. London: John Wiley \& Sons.

McGrath, B. (2012). Urban design ecologies. London: John Wiley \& Sons.

McGrath, B., Barcelloni Corte, M., \& Sangawongse, S. (2012). Structuring dynamic growth through inherited urban form: Case study from Chiang Mai, Thailand. Paper presented at ACSA Conference.

McGrath, B., \& Pickett, S. T. A. (2011). The metacity: A conceptual framework for linking ecology and urban design. Challenges, 2(4), 55-72.

McGrath, B., \& Pickett, S. T. A. (2015). An archaeology of the metacity cities. In W. Ding, A. Graafland, \& A. Lu (Eds.), Cities in transition: Power, environment, society (pp. 104-134). Rotterdam: NAI010 Publishers.

McGrath, B., \& Shane, D. G. (Eds.). (2007). Sensing the 
$21^{\text {st }}$ century city: Close-up and remote [Special Issue]. Architectural Design, 75(6).

McGrath, B., \& Shane, D. G. (2012). Meteropolis, megalopolis, metacity. In The Sage handbook of architectural theory (p. 641). New York: Sage.

Pickett, S. T. A. (2012). The ecology of the city: A perspective from science. In McGrath, B. (Ed.), Urban Design Ecologies. London: John Wiley \& Sons.

Pickett, S. T. A., Cadenasso, M. L., \& McGrath, B. (Eds.). (2013). Resilience in ecology and urban design: Linking theory and practice for sustainable cities. New York: Springer.

Picketty, T. (2014). Capital in the twenty-first century. Cambridge, MA: Harvard University Press.

Polachan, S., Pradidtan, S., Tongtaow, C., Janmaha, S., Intarawijitr, K., \& Sangsuwan, C. (1991). Development of Cenozoic basins in Thailand. Marine and Petroleum Geology, 8(1), 84-97.

Pongpaichit, P., \& Baker, C. (1998). Thailand's boom and bust. Bangkok: Silkworm Books.

Pope, A. (1996). Ladders. New York: Princeton Architectural Press.

Potter, J. (1976). Thai peasant social structure. Chicago: University of Chicago Press.

Potter, S. H. (1980). Family life in a Northern Thai village: A study in the structural significance of women. Berkeley: University of California Press

Rao, V. (2006). Slum as theory: The South/Asian city and globalization. International Journal of Urban and Regional Research, 30(1), 225-232.

Rhodes, B. P., Pereza, R., Lamjuanb, A., \& Kosuwanb, S. (2003). Kinematics and tectonic implications of the Mae Kuang Fault, northern Thailand. Journal of Asian Earth Sciences, 24(1), 79-89.

Ritchie, M. A. (1996). From peasant farmers to construction workers: The breaking down of the boundaries between agrarian and urban life in Northern Thailand, 1974-1992 (Doctoral Dissertation). Berkeley: University of California at Berkeley.

Roachanakanan, T. (2014). Articles in Planning Review of town and country planning in Thailand. Bangkok: Department of Public Works and Town \& Country Planning.

Rossi, A. (1982). The architecture of the city. Cambridge:
MIT Press.

Rowe, C., \& Koetter, F. (1978). Collage city. Cambridge: MIT Press.

Sangawongse, S., Kowsuvon, N., \& Sasom, P. (2011). Assessment of the impacts of urbanization on environmental quality in the Chiang Mai-Lamphun Valley. Journal of Remote Sensing and GIS Association of Thailand, 12(2), 1-14.

Sangawongse, S., Sengers, F., \& Raven, R. (2012). The multi-level perspective and the scope for sustainable land use planning in Chiang Mai city. Environment and Natural Resources, 10(2), 21-30.

Sangawongse, S., \& Vittaya, R. (2015). Towards a GISbased urban information systems to plan a smarter Chiang Mai. Nakhara: Journal of Environmental Design and Planning, 11, 1-8.

Scott, J. (2010). The art of not being governed: An anarchist history of upland Southeast Asia. New Haven: Yale Universtiy Press.

Shane, D. G. (2008). Recombinant urbanism. London: John Wiley \& Sons.

Surarerks, V. (2006). Muang fai communities in Northern Thailand: People's experiences and wisdom in irrigation management. Journal of Developments in Sustainable Agriculture, 1, 44-52.

Tanabe, S. (1994). Ecology and practical technology: Peasant farming systems in Thailand. Bangkok: White Lotus Press.

Tan-Kim-Yong, U. (1995). Muang-fai communities are for people: Institutional strength and potentials. Bangkok: Chulalongkorn Social Research Institute.

Tschumi, B. (1983). Manhattan transcripts. London: AA Files.

Tukamoto, Y., Kuroda, Z., \& Kaizima, M. (2001). Made in Tokyo. Tokyo: Kajima Institute Publishing.

Venturi, R., Scott-Brown, D., \& Isenour, D. (1972). Learning from Las Vegas. Cambridge: MIT Press.

Winichakul, T. (1997). Siam mapped: A history of the geo-body of a nation. Honolulu: University of Hawaii Press.

Yarnasarn, S. (1985). Land-use patterns and land-use changes in Chiang Mai, Northern Thailand (Ph.D. Dissertation). Columbia University.

\section{About the Authors}

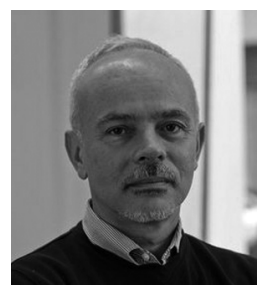

Brian McGrath is Professor of Urban Design at Parsons School of Design in New York and founder of urban-interface, LLC, an urban design consultancy with expertise in architecture, ecology and social media. His books include Urban Design Ecologies Reader (2012), Digital Modeling for Urban Design (2008), Transparent Cities (1994), Resilience in Ecology and Urban Design (2012), Growing Cities in a Shrinking World: The Challenges in India and China (2010), Sensing the $21^{\text {st }}$ Century City (2007), and Cinemetrics: Architectural Drawing Today (2007). 


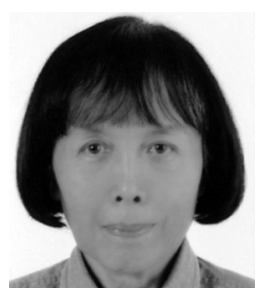

Somporn Sangawongse (Ph.D) is a lecturer and researcher in Faculty of Social Sciences, Chiang Mai University. She received a B.S. degree in Geography in 1975 from Chiang Mai University, Thailand, M. S. degree in Surveying Science from Melbourne University (1991), and a Ph.D. in Remote Sensing from Monash University (1997), Australia. Her research interests include applications of remote sensing and GIS in land use/cover mapping and modeling of urbanization process.
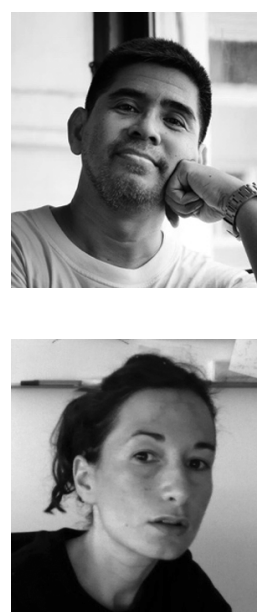

Danai Thaitakoo (Ph.D) is a lecturer in the Department of Landscape Architecture, Chulalongkorn University, Bangkok, Thailand. His research and teaching interests lie in the field of landscape and urban ecology with an emphasis on landscape dynamics and changes, urbanization, urban-rural inter-mixed. He is currently working on a research project focusing on urban-rural inter-mixed and landscape ecological changes, hydro-ecology of landscapes emphasizing interweaving between ecological infrastructures, ecological dynamics and human ecosystem in terms of resilience of landscapes and humans and ecological and cultural co-evolution.

Martina Barcelloni Corte, architect and PhD in urbanism, worked as freelancer for several international offices as EMBT-Enric Miralles Benedetta Tagliabue and Stefano Boeri Architetti, participated in the staging of several international workshops, and taught in the field of architecture and urbanism at a number of international schools as EPF Lausanne (CH), IUAV Venice (IT), Politecnico di Milano (IT), GSAPP Columbia University (US), National University of Singapore (SGP). She is now postdoctoral researcher at EPFL Lausanne since 2014 and freelance architect in Milan. 